\title{
DOES CORPORATE RETRENCHMENT GAIN VALUE? A STUDY FROM MALAYSIA
}

\author{
Lik-Jing Ung \\ Faculty of Economics and Business, Universiti Malaysia Sarawak \\ Kota Samarahan, Sarawak 94300, Malaysia \\ unglikjing@hotmail.com \\ Rayenda Brahmana \\ Faculty of Economics and Business, Universiti Malaysia Sarawak \\ Kota Samarahan, Sarawak 94300, Malaysia \\ brkhresna@feb.unimas.my \\ Chin-Hong Puah \\ Faculty of Economics and Business, Universiti Malaysia Sarawak \\ Kota Samarahan, Sarawak 94300, Malaysia \\ chpuah@feb.unimas.my
}

\begin{abstract}
Retrenchment strategy has gained its popularity and is being regarded as a common strategy in the corporate world to cut down cost. Firm owners are sceptical whether it would be a value-added strategy for their organisations. A problem arises: "Does retrenchment strategy really contribute to the firms?" Empirical research was conducted to investigate retrenchment as an influence component of the company performance. Evaluation outcomes for a sample of Malaysia firm years from 2008-2013 are analysed that included excess value, retrenchment cost, and corporate use of financial variables. From the results, we document a positive association between the excess value of retrenchment cost. Our finding is consistent with prior research where it concluded retrenchment is positively related to turnaround performance. We also examine a special moderator variable for ownership expropriation and find there is negatively and significant relationship between ownership structures and excess value, where foreign and government underperformed in imposing retrenchment strategy. However, our research further indicates that ownership concentration does not play significant role on the association between excess value and retrenchment cost. Based on the results, it suggests that retrenchment cost and ownership structure plays a monitoring role in organization strategy decision making. The implication of this research lies in two main points. Firstly, it enriches the body of knowledge by showing the effectiveness of retrenchment strategy in value creation, and the role of corporate governance on that relationship. Secondly, it contributes to regulator or policy maker that retrenchment strategy might have a good corporate governance to create value. As such, this research implies to industry that retrenchment strategy might gain value to certain type of firm and certain level of ownership. Keywords: Corporate Strategy; Excess Value; Retrenchment
\end{abstract}

\section{INTRODUCTION}

Retrenchment strategy is a common strategy that used in organization all over the world especially when firms are hampered by string of bad performances. Theoretically, retrenchment can increase performance among poorly performing firms. This strategy is not only saving troubled companies, but also it secures future potential profit. In addition, retrenchment strategy have both its benefits (Hitt, Hoskisson, Johnson, \& Moesel, 1996; Lim, Celly, Morse, \& Rowe, 2013) and costs (Bergen, Dutta, \& Walker Jr, 1992; Morrow, Johnson, \& Busenitz, 2004; Koch \& Nafziger, 2012). Nowadays, many Malaysian companies have incorporated concept of retrenchment strategy into their firm strategy plans. Therefore, this study is important to determine the merits of retrenchment strategy to the Malaysia companies across different ownership expropriations 